\title{
Bronchiolitis in a patient with talcosis
}

\author{
K Reijula, P Pääkkö, R Kerttula, O Taikina-Aho, T Tuuponen, J Hassi
}

Despite environmental monitoring, widely used occupational standards, and an increasing knowledge of the causative agents of occupational respiratory diseases, new cases of pneumoconiosis still occur. Pulmonary disorders caused by inhalation of talc (magnesium silicate, $\mathrm{Mg}_{3} \mathrm{SI}_{4} \mathrm{O}_{10}(\mathrm{OH})_{2}$ ) have been described among workers in various industries. ${ }^{12}$

Interstitial inflammation with lymphocytic infiltration, granulomas, and birefringent material are typical findings in lung tissue of patients with talcosis. ${ }^{12}$ Bronchiolar changes, however, have never been described and this paper is the first report of bronchiolitis in patients with talcosis.

\section{Case report}

A 43 year old talc mine loader who operated a tractor was admitted to a local chest hospital with dyspnoea, cough, and phlegm. He had worked as a talc loader since 1960. The patient used paper masks only occasionally to prevent dust inhalation. Mineralogical examination had established that talc from the talc mine occurs in plate and granular forms but not in fibrous form. Personal dust samples were collected inside the tractor during talc loading in 1976 and 1986 . The total dust concentration was 86 $\mathrm{mg} / \mathrm{m}^{3}$ in 1976 after which time dust filters were installed into the artificial ventilation system of the tractors. In 1986 the total dust concentration was 3.5 $\mathrm{mg} / \mathrm{m}^{3}$.

The patient had smoked 20 cigarettes a day for 21 years. Contact dermatitis due to nickel was found in patch tests in 1976. He had no history of allergic rhinoconjunctivitis, atopic dermatitis, or other significant diseases.

He had had dyspnoea, cough, and production of

Oulu Regional Institute of Occupational Health, SF 90100 Oulu, Finland

K Reijula, R Kerttula, J Hassi

Department of Pathology, Oulu University, Oulu, Finland

P Pääkkö

Institute of Electron Optics, Oulu University, Oulu, Finland

O Taikina-Aho

Päivärinne Chest Hospital, Jokirinne, Finland

$\mathrm{T}$ Tuuponen phlegm for eight months. Cough and phlegm occurred both in the mornings and during the work shift. He had dyspnoea only when heavy dust was present and a few hours after exposure to talc dust. The symptoms diminished during weekends. He was admitted to Päivärinne chest hospital where tests of lung function showed a restrictive ventilatory defect and decreased diffusing capacity (table). No abnormalities were detected on chest $x$ ray film or in routine laboratory tests. No bronchial hyperreactivity was found by metacholine bronchodilator (salbutamol).

Precipitating antibodies to Aspergillus fumigatus, A umbrosus, Thermoactinomyces vulgaris, and Faenia rectivirgula (Micropolyspora faeni) could not be detected in the patient's serum by immunodiffusion tests. Cultures for $M$ tuberculosis, other bacteria, and fungi were negative and eosinophilic granulocytes were not present in sputum. All tests to measure antibodies to viral agents were negative. Antinuclear antibodies or rheumatoid factor were not found. Skin prick tests with nine inhalant allergens were negative for immediate weal and flare reactions.

The patient was treated with a bronchodilator (salbutamol) for three months after which he was reexamined. He complained of shortness of breath and wheezing after inhaling dust at work, during exercise, and when breathing cold air. A slight improvement was found in diffusing capacity values. Other lung functions were unchanged. No remarkable changes had occurred in laboratory tests or on chest $x$ ray film. Theophylline treatment was added to the patient's regimen.

During a third examination an improvement of $\left(\mathrm{FEV}_{1}\right)(30 \%)$ was noted after treatment with salbutamol. The daily range of peak flow values was 500-600 1/minute. The patient was treated with prednisolone for one week without an improvement in symptoms or lung function.

After six months without medication he presented with increased dyspnoea, cough, and wheezing, which had occurred during dust inhalation at work. Lung function tests were unchanged. Blood eosinophil $\left(509 \times 10^{6} / 1\right)$ and total serum IgE concentrations (159 $\mathrm{IU} / \mathrm{ml})$ were slightly increased. With bronchodilator treatment an improvement of $\mathrm{FEV}_{1}(20 \%)$ was found. During treatment with salbutamol in hospital the mean peak flow values also improved. 
Clinical data for patient with talcosis

\begin{tabular}{|c|c|c|c|c|c|}
\hline Data & November 1982 & June 1983 & November 1983 & April 1984 & February 1986 \\
\hline \multicolumn{6}{|l|}{ Lung function: } \\
\hline $\begin{array}{l}\text { FVC (1) } \\
\text { FEV } 1 \text { (1) } \\
\text { FEV } 0 \\
\text { DI.Co (1) } \\
\text { RV (1) } \\
\text { TLC (1) }\end{array}$ & $\begin{array}{cc}3.89 & (75)^{\star} \\
3 \cdot 10(75) \\
84 & \\
23 \cdot 4 & (75) \\
1.16 & \\
5.05 & \end{array}$ & $\begin{array}{cc}3 \cdot 77 & (72) \\
2 \cdot 74 & (65) \\
81 & \\
24 \cdot 3 & (78) \\
0.91 & \\
4 \cdot 70 & \end{array}$ & $\begin{array}{c}3.43(66) \\
2.88 \quad(67) \\
84 \\
24 \cdot 4 \quad(79) \\
0.87 \\
4 \cdot 30\end{array}$ & $\begin{array}{cc}3.73 & (70) \\
3.21 & (79) \\
86 & \\
26.5 & (80) \\
0.88 & \\
6.68 & \end{array}$ & $\begin{array}{cc}4 \cdot 29 & (85) \\
3 \cdot 32 & (85) \\
77 & \\
24 \cdot 2 & (77) \\
0.99 & \\
5 \cdot 50 & \end{array}$ \\
\hline $\begin{array}{l}\text { Laboratory tests: } \\
\text { ESR (mm h) } \\
\text { B-leuc }\left(\times 10^{4} 1\right) \\
\text { B-eos }\left(\times 10^{n} 1\right)\end{array}$ & $\begin{array}{c}7 \\
9 \cdot 7 \\
300^{7}\end{array}$ & $\begin{array}{c}7 \\
8 \cdot 3 \\
269\end{array}$ & $\begin{array}{c}9 \\
11 \cdot 0 \\
509\end{array}$ & $\begin{array}{c}8 \\
10 \cdot 0 \\
253\end{array}$ & $\begin{array}{r}7 \\
8 \cdot 0 \\
231\end{array}$ \\
\hline
\end{tabular}

^Numbers in parentheses are percentages of predicted values.

FVC = forced vital capacity; FEV $1=$ forced expiratory volume in one second; FEV $\%=$ FEV $/$ FVC $\times 100 ;$ DLco $=$ diffusing capacity for carbon monoxide; $\mathrm{RV}=$ residual volume; $\mathrm{TLC}=$ total lung capacity; $\mathrm{ESR}=$ erythrocyte sedimentation rate; $\mathrm{B}-\mathrm{leuc}=\mathrm{blood}$ leucocyte concentration; B-eos = blood eosinophil concentration.

Five months later he presented with increasing dyspnoea, cough, and fever. Chest $x$ ray film showed diffuse, soft densities in the middle and lower lung zones. Further changes in lung function or in laboratory tests were not found. A transbronchial biopsy was performed and showed granulomatous

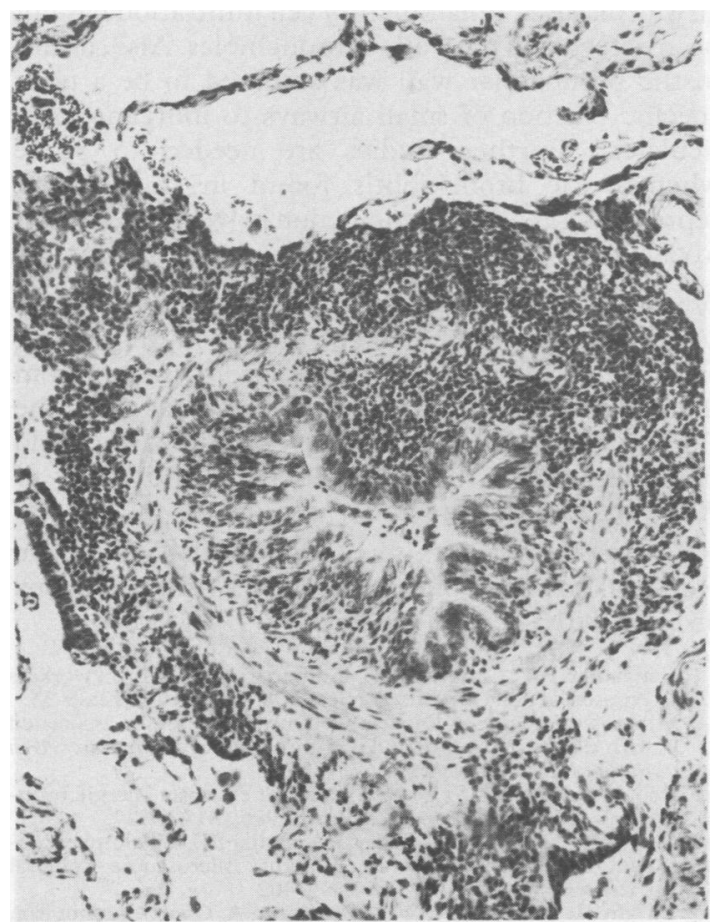

Figure 1 Light micrograph of open lung biopsy showing a bronchiole with mucosal infiltration of mononuclear inflammatory cells, mainly lymphocytes and plasma cells $(H$ and $E \times 100)$. infiltration with macrophages including birefringent material. An open lung biopsy was conducted in May 1984 to elucidate the definite etiology of the granulomatous lung infiltration. Biopsy specimens were treated as described earlier. ${ }^{3}$ The samples containing dust were examined using a JEOL 100 STEM fitted with a PGT 1000 energy dispersive spectrometer at $100 \mathrm{kV}$.

Light microscopy showed a fairly normal alveolar pattern. Most of the non-respiratory and respiratory bronchioles had lymphocytic infiltration of the mucosa (fig 1). A few interstitial epithelioid cell granulomas were seen. Slight fibrosis was found in the interstitium, with hypertrophy of arterial media. Interstitial tissue contained black dust, especially around muscular arterioles, bronchioles, and in subpleural areas; several birefringent crystals or sticks were seen in polarised light. Multinucleated giant cells were also present. Some of these contained either a few dust particles or asteroid bodies. The histological picture suggested talcosis.

Interstitial macrophages that contained one or two particles a cell were detected by electron microscopy (fig 2a). These particles showed a spectrum typical of talc in energy dispersive $x$ ray analysis (fig $2 \mathrm{~b}$ ). No silica or asbestos was detected in the lungs.

After the lung biopsy the patient continued treatment with a bronchodilator. He returned to work two months later and irregularly used a helmet type ventilatory device. Eight months later he presented with less severe dyspnoea, cough, and phlegm without fever. No remarkable changes were found in lung function tests. His oxygen saturation and electrocardiogram were normal both at rest and during exercise. Peak flow values varied from 520 to 6001 per minute. Bronchial hyperreactivity by metacholine provocation test could not be detected. The patient retired in February 1986. 


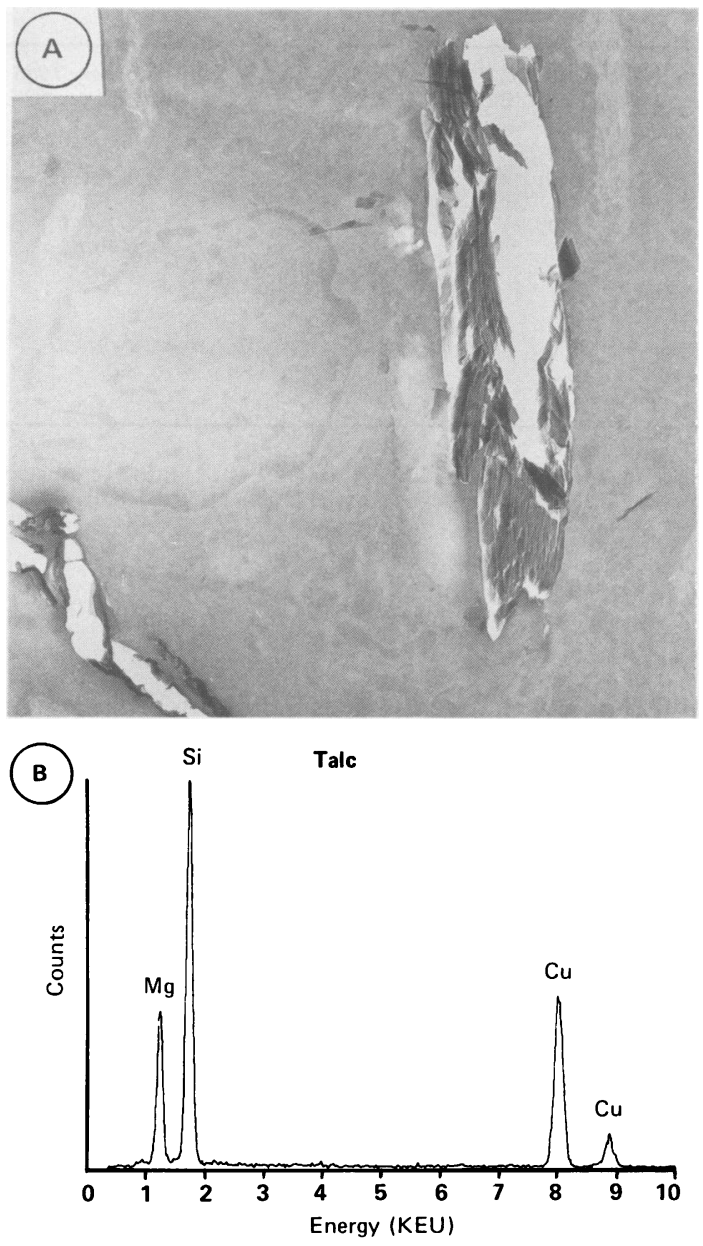

Figure 2 (A) Electron micrograph of two talc particles in a pulmonary interstitial macrophage $(\times 6700)$. (B) Energy dispersive $x$ ray analysis spectrum of a typical talc particle $\left(\mathrm{Mg}_{3} \mathrm{SI}_{4} \mathrm{O}_{10}(\mathrm{OH})_{2}\right)$ with spikes of $\mathrm{Mg}$ and $\mathrm{Si}(\mathrm{Cu}$ originates from supporting grid).

\section{Discussion}

The diagnosis of talc pneumoconiosis should be established by a history of prolonged exposure to talc dust, to radiological appearance of pulmonary infiltrations, histological findings, and by the finding of talc particles in the lungs after mineralogical or electron microscopy examination, or both. Electron microscopy has extended the capability for diagnosis of pneumoconioses. Furthermore, the composition of foreign material in the lungs can be determined by energy dispersive $x$ ray analysis.

In the present study, dust samples that were measured in the breathing zone of the patient during the working shift showed high concentrations of talc inside the tractor. The patient started to use a sufficient ventilatory device (irregularly) only after the first clinical examination. Thus exposure to talc dust was most evident before the clinical examinations.

As in previous studies, dyspnoea and cough were the first symptoms. ${ }^{24}$ It is difficult to estimate the onset of the respiratory symptoms caused by talc dust because of the patient's heavy smoking, which undoubtedly explains some of the symptoms suggesting chronic bronchitis. The patient noticed, however, an increase in the symptoms, which he related to inhalation of talc dust, and which appeared eight months before the first examination. As previously described, a restrictive ventilatory defect with reduced vital capacity was detected. ${ }^{4}$ Also, a slight decrease in diffusing capacity and an obstructive ventilatory defect were found, together with lymphocytic infiltration of the mucosa of non-respiratory and respiratory bronchioles. Bronchiolitis has not been shown previously in talcosis. The obstructive ventilatory defect may be partly explained by bronchiolitis in this case.

Recent studies have shown that non-asbestos mineral dust can cause small airway lesions accompanied by air flow obstruction. ${ }^{5}$ These lesions, with deposits of fibres and pigmentation, have been detected in the walls of non-respiratory and respiratory bronchioles and alveolar ducts. ${ }^{6}$ In this "mineral dust airway disease" inflammatory cell infiltration has not been detected in the walls of bronchioles. Also, injury to the bronchiolar wall was assumed to be a nonspecific reaction of small airways to inorganic particulates. ${ }^{6}$ Further studies are needed to prove whether the bronchiolitis found in this patient represents a general phenomenon in workers exposed to talc dust.

We thank Eeva Liedes MD, Jordan Fink MD, and Victor Ferrans MD for their interest in the present study. The work has been supported by grants from the Finnish Antituberculosis Association, the Finnish Work Environment Fund, the Paulo Foundation, and the Foundation for the Study of Allergy, Helsinki, Finland.

Requests for reprints to: Kari Reijula MD, Oulu Regional Institute of Occupational Health, PO Box 451, SF-90101 Oulu, Finland.

1 Vallyathan NV, Craighead JE. Pulmonary pathology in workers exposed to nonasbestiform talc. Hum Pathol 1982;12:28-35.

2 Silicosis and Silicate Disease Committee. Diseases associated with exposure to silica and nonfibrous silicate minerals. Arch Pathol Lab Med 1988;112:673-720.

3 Reijula K, Sutinen S. Ultrastructure of extrinsic allergic bronchiolo-alveolitis. Pathol Res Pract 1986;181:418-29.

4 Miller A, Terstein AS, Bader RA, Selikoff IJ. Talc pneumoconiosis. Significance of sublight microscopic mineral particles. Am J Med 1971;50:395-402.

5 Wright JL, Harrison N, Wiggs B, Churg A. Quartz but not iron oxide causes air-flow obstruction, emphysema, and small airways lesions in the rat. Am Rev Respir Dis 1988;138:129-35.

6 Churg A, Wright JL. Small-airway lesions in patients exposed to nonasbestos mineral dusts. Hum Pathol 1983;14:688-93.

Accepted 6 August 1990 